\title{
Gender Gaps in Policy Making: Evidence from Direct Democracy in Switzerland
}

\author{
Patricia Funk \\ Universitat Pompeu Fabra \\ Christina Gathmann \\ Stanford University
}

This Draft: November 2008

\begin{abstract}
In spite of increasing representation of women in politics, little is known about their impact on policies. Comparing outcomes of parliaments with different shares of female members does not identify their causal impact because of possible differences in the underlying electorate. This paper uses a unique data set on voting decisions to sheds new light on gender gaps in policy making. Our analysis focuses on Switzerland, where all citizens can directly decide on a broad range of policies in referendums and initiatives. We show that there are large gender gaps in the areas of health, environmental protection, defense spending and welfare policy which typically persist even conditional on socio-economic characteristics. We also find that female policy makers have a substantial effect on the composition of public spending, but a small effect on the overall size of government.
\end{abstract}

Keywords: Female Policy Makers, Political Gender Gaps, Switzerland

*Correspondence: Patricia Funk, Department of Economics, Universitat Pompeu Fabra, Email: Patricia.Funk@upf.edu; Christina Gathmann, CHPR/PCOR, Stanford University, Email: cgathman@stanford.edu.

A previous version of this paper has been circulated under the title "What Women Want: Suffrage, Gender Gaps in Voter Preferences and Government Expenditures".

We thank Renee Adams, Ulf Axelson, Francine Blau, Tore Ellingsen, Daniel Ferreira, Mariassunta Gianetti, Henning Hillmann, Humberto Llavador, Rohini Pande, Michèle Tertilt, seminar participants of Stockholm Institute of Transition Economics, the Stockholm School of Economics, University of Uppsala, University of St. Gallen, Stanford University, SITE conference, the Midwest Political Science Association and the 6th Trobada Barcelona Economics for useful comments and suggestions. We are grateful to Francois Loretan from SIDOS for invaluable help with the data. Patricia Funk gratefully acknowledges financial support from the Swedish Research Council Vetenskapsradet. 


\section{Introduction}

Compared to their share in the population, women are still under-represented in politics. In response, many countries have passed or planned gender quotas, which reserve a certain share of seats in parliament for women. For instance, France not only enacted direct quota for members of parliament at the national and state level, but also for electoral candidates. In a similar spirit, a female German Social Democrat (Lissi Groener) campaigns for half of the top jobs in EU institutions to be reserved for women (the Economist, 2008).

In light of this increasing pressure to boost the presence of women in politics, it is important to understand whether and where gender gaps in policy making exist. At one extreme, if women and men have the same policy preferences, then quotas would have no effect and hence be unnecessary. Yet, research on voting behavior for both parties and presidential candidates suggests that women and men do have different preferences for parties or candidates (see e.g. Edlund and Pande, 2002; Edlund, Haider and Pande, 2005). ${ }^{1}$ However, votes for candidates or political parties are typically based on a bundle of characteristics and not necessarily informative on the individual's preferences for specific policies.

At the other extreme, different policy preferences between men and women would not affect policies if politicians would solely represent the median voter, i.e. they can commit to a policy platform and care only about their reelection. Data on roll call votes in the United States however provide strong evidence against this Downsian model of the political process (see Levitt, 1996; Washington, 2008).

Hence, a natural approach to measure political gender gaps would be to analyze the behavior of female policy makers relative to their male colleagues (e.g. Thomas, 1991). The key challenge of this approach is that the share of female policy makers is endogenous, and typically correlated with

\footnotetext{
${ }^{1}$ Gender differences are increasingly discovered in other fields as well. For instance, Niederle and Vesterlund (2007) show that women prefer less competitive environments with lower risk. Rangel (2006) documents gender heterogeneity in preferences among cohabiting couples in Brazil. Duflo (2003) documented gender gaps in behavior in a pension reform in South Africa. Adams and Ferreira (2008) report different behavior of male and female directors in US companies.
} 
the political preferences or other characteristics of the electorate in the respective state or district. The only evidence with random variation in female politicians is available for India (Chattopadhyay and Duflo, 2004). Based on imposed mandates for female village leaders in India, the results show that women allocate resources to projects supporting women's needs, for example, public investments in fresh drinking water. Yet, it is not obvious whether these results can be generalized to the very different political issues in the developed world.

This article exploits another political context to shed new light on gender gaps in policy making in Europe. In particular, we make use of the direct democratic setting in Switzerland where the electorate makes political decisions on a broad range of policy issues with real political and fiscal consequences two to three times a year. Over the last fifty years, more than 300 ballots votes have been held at the federal level alone. Hence, political decisions at the ballot play a prominent role in Swiss politics and make Switzerland the leading direct democracy in the world (Trechsel and Kriesi, 1996). Our analysis uses survey data of individual voting behavior for all federal votes between 1981 and 2003.

Our setting has a number of attractive features. Most importantly, we provide empirical evidence for the importance of political gender gaps in an advanced European democracy. This type of evidence is very difficult to identify because voting records for individual parliamentary members are not available in most European countries. Though we rely on a direct democratic setting for the analysis, we believe that our insights are not restricted to direct democracies. Rather, we expect similar gender effects in the more representative democracies in Europe, especially as more and more women gain seats in national and state parliaments through regular elections or legal means like quotas.

A second advantage of our context is that the federal ballots cover a very wide range of political issues and have real financial consequences, for example, in health policy, changes in unemployment insurance, new environmental policies, subsidies for agriculture or membership in international organizations. Our focus on political decision-making at the federal level allows us to study policy areas like defense which typically cannot be analyzed with data at the subnational level. 
Furthermore, our direct democratic setting is unique because there is little incentive for citizens to vote strategically. The direct democratic setting ensures that the ballot with the majority of votes is implemented. Hence, citizens have no incentive to vote for anything different than their preferred policy. We therefore identify "genuine" gender gaps in preferences for policies. In contrast, roll call votes of individual politicians are likely to be strongly influenced by strategic motives, for example, log-rolling or reelection concerns.

Finally, we study the political gender gaps in the electorate, i.e. the population of political decisionmakers rather than the selected pool of elected female representatives. Since gender quotas propose a substantial increase in the political representation of women (for example, 30 to 40 percent of seats in parliament for female candidates), it is likely that gender quotas alter the type of female politicians elected. In addition, it is also possible that gender quotas would reduce political competition, which increases the scope of policies where women politicians' can implement their own preferences (ideology) compared to the case of unrestricted elections. Hence, we think our results for the electorate at large are policy-relevant and complement existing evidence on currently elected politicians.

Three main results emerge from our empirical analysis: First, we document that there are substantial gender gaps in the approval for policies. Women are more in favor for public health provisions, equal rights for men and women, environmental protection, unemployment and social security provisions. At the same time, they are also less in favor of nuclear energy and the military. Second, we show that the gender gaps rarely disappear if observables are controlled for. Even when women and men are equal in terms of education, marital status, employment and income, women still approve more projects to protect the environment or support the disabled, but oppose an expansion of the military. We also find few differences in voting behavior for women with different educational background, marital or employment status.

Finally, we investigate the financial consequences of including more female decision makers. For that, we restrict the analysis to the sample of federal votes that would have raised government spend- 
ing, taxes or debt. Overall, we find that women are only modestly more inclined to approve projects that increase the size of government. Compared to men, they were 2.5 percent more likely to approve such proposals. On the other hand, female policy choices greatly affect the composition of government expenditures. Women were 14 percent more likely to support spending for protection of the environment and 7 percent less likely to support spending on military. Hence, an increase in the number of female political decision makers is likely to have big effects on the composition, but small effects on the overall size of government spending.

Our results are related to three strands of the literature. First, our study enhances our understanding of female policy makers. Compared to (quasi-)experimental evidence from India (Chattopadhyay and Duflo, 2004; Clots-Figueras, 2008a; 2008b) and for state policy makers in the United States (Rehavi, 2007), we analyze for the first time female policy makers in the European context. In addition, we identify gender gaps in policy making for the electorate at large and in the absence of incentives for strategic voting behavior. Hence, we view our analysis as complementary to the existing studies from India and the United States.

Second, we shed light on the debate whether political involvement of women increases the size of government. While for the United States, women's suffrage seemingly increased state level spending (Lott and Kenny, 1999; though Miller (2008) reports an insignificant estimate), results for Europe are mixed (Aidt, Duta and Loukoianova, 2006; Aidt and Dallal, 2008). In contrast to these studies using aggregate state-level data, we rely on individual data on actual policy choices. Our study does not allow us to estimate the overall effect of women's suffrage which might also affect government spending through party platforms or elected candidates. However, the advantage of our approach is that we can identify gender gaps in actual political choices with real financial consequences in a very direct way. Our results support the view that inclusion of female preferences in the political decision making process has small effects on total spending.

Finally, our results are also related to a strand of literature in political science which explores 
gender gaps in voter preferences. While the large bulk of literature deals with the electoral gender gap (see e.g. Inglehart and Norris, 2003), some studies try to elicit gender gaps in policy preferences from opinion polls like the General Social Survey, the Gallup or National Election Surveys (see e.g. Shapiro and Mahajan, 1986; Mueller 1988). ${ }^{2}$

While these studies are suggestive, the questions asked are often fairly general and typically do not involve decisions about concrete projects and how they would be financed. Furthermore, the answers given to hypothetical questions on the role of government may differ substantial from actual behavior. Matsusaka and McCarty (2001), for instance, found that hypothetical questions from opinion polls can be very bad predictors for later voting behavior. In our data on voting in Swiss federal ballots, citizens vote on specific projects for which the political and financial consequences are well-known and accessible to the voters. Hence, the political choices made by Swiss men and women are closer to the set of political issues faced by parliamentary members in modern democracies.

The rest of this article is structured as follows. Section 2 introduces the Swiss political context and describes our data. Section 3 analyzes the gender gaps in voting and section 4 sheds light on the fiscal consequences of female policy makers. Conclusions are presented in section 5 .

\footnotetext{
${ }^{2} \mathrm{~A}$ comparable data source for Europe would be the Eurobarometer, a public opinion survey in the EU member states. There are however few surveys that directly ask for allocation of governmental resources. Only in the survey of March/April 1984 (wave 21), seventeen questions were asked whether government spending is too little/about right/ too much in a certain policy area. However, the questions do not discuss how the money would be actually spent or how the additional spending would be financed.
} 


\section{Data on Voting Behavior in Federal Propositions}

To analyze differences in policy choices between men and women, we make use of the fact that Switzerland has wide-ranging possibilities for direct democratic participation. In particular, we focus on the political decisions of citizens at the federal level, which include important policies such as the military and foreign policy which can typically not be studied using state-level data.

At the federal level, citizens can propose an initiative for a partial or total revision of the federal constitution. In addition, they can request a referendum about all laws issued by the federal government if 50,000 signatures are collected. Furthermore, a voter referendum is mandatory for any changes to the constitution and all international treaties. As a consequence, citizens vote on several federal ballots two to three times each year.

In Switzerland, every person older than 18 is allowed to vote (before March 1991, the minimum age was 21). No registration is necessary, and every eligible person automatically receives the official documents to vote which includes detailed information on the ballot to be decided. Specifically, the information package of the federal government contains the arguments for and against the proposition, a printed version of the parliamentary debate (if any) and often outside opinions by interest groups. ${ }^{3}$ Furthermore, the distributed documents contain the estimated financial consequences, i.e. whether and by how much expenditures or taxes would increase if the proposition was approved.

Hence, Swiss citizens have easy access to information about the ballots both through the distributed documents and discussions in the media. In our data, 78 percent of voters report that they were well informed about the ballot prior to the vote. Furthermore, they have practiced their direct democratic participation rights for more than a century at the federal level. Consequently, we believe that the electorate is able to make informed choices about the proposed ballots.

The data we use for our analysis of federal ballots are taken from the VOX surveys, which are

\footnotetext{
${ }^{3}$ These documents can be accessed online at http://www.ads.bar.admin.ch/ADS/showHome.do.
} 
conducted by telephone shortly after each vote, to elicit information on voting behavior. Overall, we have data for 197 of the 202 federal propositions held between 1981 and 2003.

The survey is a repeated cross-section, which collects data on a representative sample of 1,000 (700 before 1987) Swiss citizens. The survey asks about the voting decision in the last federal ballot, whether the respondent was informed about the propositions. It also collects information on general political attitudes and party preferences as well as the respondent's demographic and economic situation. ${ }^{4}$ Since we are interested in comparing choices of female and male voters, we dropped all respondents under the age of twenty-one, who were not eligible to vote until March of 1991, and under eighteen thereafter. We further restrict our sample to respondents that actually voted in the federal ballot.

Our data have a number of attractive features for measuring policy preferences: first, we use information on voting behavior with real political and financial consequences. Since every eligible voter receives detailed information about these consequences before each vote, we consider the voting decisions as a more reliable indicator of policy preferences than hypothetical questions from opinion polls.

In addition, the policy choices are representative for the electorate as a whole since individuals in all cantons vote on the same proposition. Finally, the votes cover a wide range of political issues, such as health policy, changes in unemployment insurance, new environmental policies, subsidies for agriculture or membership in international organizations. While the set of issues decided at the ballot box does not coincide with the set of decisions taken by members of parliament, the political choices, many about redistribution or the provision and financing of public services is nevertheless informative about policy preferences of men and women.

Table 1 reports summary statistics of the survey data separately for men and women over the period from 1981 to 2003 . The table reflects the more traditional position of women in Swiss society: women are on average less educated than men and have lower income available to them. The female

\footnotetext{
${ }^{4}$ More information on the survey and data is available online at http://www.gfsbern.ch.
} 
labor force participation rate is low compared to the United States as is the fraction of divorced people. Women in the sample are also more likely to live in urban areas and in the French- and Italian-speaking cantons of Switzerland.

— insert Table 1 about here -

\section{$3 \quad$ Gender Gaps in Policy Making}

We first identified the votes with the largest gender differences in approval for the complete sample of the 197 votes held between 1981 and 2003. Table 2 shows the ten votes with the largest differences in approval rates between men and women. To get a better idea about the content of these votes, the Appendix briefly describes the main goals and fiscal implications.

As can be seen from Table 2, women were 18 percent more likely to support an initiative for a reduction in tobacco consumption. More generally, women are much more supportive of votes to promote a healthy lifestyle and environmental protection. They are also somewhat more in favor of redistribution. Not surprisingly, women were also more likely to support votes for the equal representation of women in the federal government, equal rights for men and women in general and a reform of marital law. In addition, women were more supportive of anti-discrimination policies, environmental policy and government subsidies for the disabled. On the other hand, they oppose the use of nuclear energy (see also Longchamp and Bieri, 2001).

— insert Table 2 about here —

While suggestive, our summary statistics also show that women in the sample differ along other observable dimensions from men, for example, they are more likely to live in urban areas and have less 
income. To control for such possible confounding factors, we now turn to a more systematic analysis of political gender gaps.

Subsequently, we focus on seven main policy areas: three areas cover public goods (environment, transportation and defense), two the public provision of a private good (education, health), and two areas are about transfers and redistribution (agricultural subsidies, social security provisions). To classify the federal ballot propositions into the seven policy areas, we used the title and description of the vote. Table 3 shows a list and further information for all the votes in each policy area. For example, nine votes on environmental protection have been held, ranging from the introduction of car-free Sundays to subsidize solar energy with governmental funds.

Since a vote of yes might not be equivalent with supporting a certain policy, we defined a person's vote within each policy area in such a way that it supports always more or always less of a policy. For example, all votes on agricultural policy are coded such that a vote of 'yes' implies supporting a reduction in agricultural subsidies.

— insert Table 3 about here -

The model we then estimate is

$$
\text { Yes }_{i j t}=\alpha+\beta_{j} \text { Female }_{i}+\gamma^{\prime} X_{i t}+\varepsilon_{i j t}
$$

where $Y e s_{i j}$ is a binary variable equal to one if respondent $i$ supported a vote in policy area $j$ at time $t$ and zero otherwise. $X_{i t}$ includes other control variables.

We start out with controls for the region of residence and urban environment. This very parsimonious specification will provide a sense of where gender gaps in policy choices exist. Later on, we will also check whether women's and men's voting choices differ even conditional on other observable differences such as income, employment status and education. These conditional estimates will shed 
some light on the sources of gender gaps. However, to the extent that women earn less than men, it is the combined effect of lower income and gender that is of interest when evaluating the political and fiscal consequences of more female policy makers.

Table 4 reports marginal effects from a probit model of the voting decision in each policy area. All specifications include year and canton of residence fixed effects. With the exception of one vote in the area of secondary education, there are substantial gender differences in approving policies. For instance, women have an 8.4 percentage point higher probability of supporting projects that protect the environment. Also, women are more likely to oppose an expansion of the army, or granting subsidies for agriculture. On the other hand, they support subsidies for health insurance and other redistributive programs.

— insert Table 4 about here -

The fact that women opposed a reduction of benefits for the unemployed (see welfare) or supported subsidies for health insurance raises the question what drives these gender gaps.

The traditional explanation by economists is based on differences in labor market opportunities and income. The Meltzer and Richard (1981) model of the demand for government shows that voters with less income will be more in favor of redistributive measures like progressive taxes or transfers. Lott and Kenny (1999) have used this setup to explain why women's suffrage may have increased the size of government. Similarly, Edlund and Pande (2002) explain women's shift to the left after the 1980s with an increase in the risk of divorce, which enhances women's taste for redistribution due to their lower expected income.

Do we see a similar mechanism at work in our data? If income differences are the source behind the gender gaps, they should disappear once we condition on income in the regressions. And are income and other labor market differences mainly relevant for redistributive policies or do they influence policy choices more generally? 
To explore this question more systematically, we re-estimate the gender gaps in the seven policy areas while controlling for education, marital status and employment. We also include home ownership as a proxy for income because direct questions on household income were included in very few votes (we will however come back to this issue in the robustness section).

Table 5 shows that the estimated gender gaps are generally not much affected by the inclusion of controls. Gender gaps disappear only for certain redistributive policies like subsidies for health insurance or a reduction of unemployment benefits conditional on controls for earnings opportunities. However, there are still many policy areas, including environmental protection, defense policy and support for old age and the disabled, where women have different policy priorities from men even conditional on differences in socio-demographic factors. ${ }^{5}$

— insert Table 5 about here —

Finally, we were interested in seeing whether different sub-groups of women made different policy decisions. Clots-Figueras (2008a, 2008b) found that female policy makers in India chose quite different policies depending on the cast they were born into. Table 6 compares the policy choices of women with different educational achievements. The interaction terms between female and education are statistically insignificant in most policy areas. Similarly, we did not find strong evidence that married women make systematically different choices from single or divorced women; or that home ownership and employment status mattered much (not reported). In some cases, there was potentially not enough variation to detect differences among different groups of women. ${ }^{6}$ These results suggest that the set of

\footnotetext{
${ }^{5}$ One factor why gender gaps in redistributive policies persist even conditional on income could be differences in beliefs about the sources of income differences between men and women. For example, Fong (2001) and Alesina and Ferrara (2005) found that whether one believes that effort or luck drive differences in income has important implications for individual preferences for redistribution in addition to one's own position in the income distribution.

${ }^{6}$ The results are available upon request.
} 
chosen policies, at least in a highly developed country like Switzerland, might not differ much whether female policy makers are recruited from a quite selective or a broader pool of citizens.

— insert Table 6 about here -

\section{The Fiscal Consequences of Women Policy Makers}

So far, we analyzed gender gaps in approval rates for proposed policies independently of their fiscal consequences. Suppose however, that women are for instance fiscally more conservative than men. Then, they may not favor costly projects for environmental protection even though they may care more about it than men.

This section provides more detailed evidence on whether women and men differ in how they like to allocate government resources. To analyze the fiscal policy preferences of men and women, we selected from the 197 federal ballots those that would unambiguously increase or decrease government spending.

In order to assess the fiscal impact of each proposition, we used the official documents prepared by the government, which outlines the estimated financial consequences, i.e. whether and by how much spending would increase if the proposition was approved by the electorate. After careful study, we identified 71 propositions between 1981 and 2003 where the documents showed unambiguous financial consequences. Table A1 in the Appendix contains a detailed list of these votes. Note that the set of propositions we analyze contains both ballots that were approved and therefore actually increased government spending as well as ballots that were not successful. Hence we have a representative set of actual political decisions and their financial consequences, which is not affected by the ballot's actual success. 
The model we estimate is the same as in the last section except that we now use only the subset of votes with predictable financial consequences. Table 7 shows marginal effects from a probit model whether a respondent voted yes on a proposition that would increase overall government spending as well as spending in the seven different policy areas (education, health, welfare, environment and nuclear policy, defense spending, transportation and agricultural policy). ${ }^{7}$

The first column shows that women are 2.5 percent more likely to support projects that would increase overall government spending. They are also 2.5 percent less likely to support a reduction of government debt though the coefficient is not significantly different from zero. For overall spending, it is surprising that, despite large gender gaps in several policy areas, there are relatively small differences in the approval of costly projects between women and men.

Note further that actual spending is only affected by women's political participation if the proposition is approved by the voters and women changed the final outcome, i.e. they proved to be pivotal. Among all federal ballots between 1981 and 2003, women and men had approved different outcomes in fifteen votes (see table A2 for a list of those votes). Women changed the result in their favor in only four cases or about two percent of the 202 propositions over that period. From these four pivotal votes, only two had clear-cut fiscal implications.

Based on the information provided by the federal government before the vote, we can get a rough estimate of the consequences of these two fiscally relevant votes. Women's opposition to a reduction in unemployment benefits increased federal spending by about 70 million Swiss Francs per year. However, women were also in favor of abolishing subsidies for parking spaces, which saved the federal government about 20 million Swiss Francs per year. Relative to the 46 billion federal expenditures in 1999, the change in voting outcomes by women adds up to a mere 1.1 percent increase in federal spending.

Obviously, we can only evaluate the financial impact of female voters for decisions that are taken

${ }^{7}$ If the ballot proposed a reduction of spending, taxes, subsidies or debt, we rescaled the voting choice as one if the respondent did not vote for the measure and zero if she approved a reduction in government spending in that area. 
at the ballot box. It is possible that women might also have increased spending through at least two other channels: first, the composition of the parliament by electing different representatives or different parties. Second, women can also affect policies directly by proposing initiatives that support their policies. However, reduced form estimates find little evidence that women's suffrage increased overall governments spending in the Swiss cantons in the second half of the twentieth century (see Funk and Gathmann, 2007; Stutzer and Kienast, 2005). Hence, it appears that the effect of women policy makers on the overall size of government is limited.

— insert Table 7 about here —

However, the picture changes if we look at the different policy areas. Here, we find that women are 14 percent more in favor of policies that support environmental protection. At the same time, they are also 7 percent less likely to support agricultural or military spending. In addition, they are also more supportive of health and welfare spending than men. As such, female policy makers have affected the composition of government spending much more than the overall size of government.

Table 8 uses the same specification but also adds various control variables. Again, the size of the estimated female dummy variable is little affected by these controls. However, since more controls are available for a subset of votes, we analyzed as a robustness check whether inclusion of household income, kids and knowledge of the voter affects the estimated gender dummy (see Table 9). The right comparison is to first estimate the female dummy for the subset of votes where these controls were asked for (as a baseline) and then to add the controls in a second set of regressions. As can be seen from Table 9, neither adding household income, a dummy for having kids or a knowledge indicator changes the estimated female dummy compared to the baseline estimate greatly.

These estimates therefore confirm our previous results that by and large the gender gaps in the Swiss electorate cannot be explained by differences in socio-demographic characteristics. 
— insert Tables 8 and 9 about here -

\section{Conclusion}

This paper provides new evidence on the impact of female policy makers in a European context. So far, empirical evidence has been scarce because comparing policies in states/countries with different shares of women in parliament is subject to endogeneity with respect to underlying characteristics of the electorate. Furthermore, information on parliamentary votes is not available for most advanced European democracies. To circumvent these issues, we exploit the direct democratic setting of Switzerland where citizens directly decide on many issues like redistributive policies, defense spending, infrastructure investments or environmental protection. Another advantage of our setting is that we can analyze gender gaps for different types of policies (federal instead of state level) as well as for a broader range of categories than previously possible.

We find strong evidence that women and men in Switzerland support a different allocation of government resources. In particular, we show that female policy makers care more about the environment, public health, social welfare and are more skeptical towards nuclear energy or the military. Regarding the fiscal consequences of female policy makers, we find a bigger impact on the composition rather than the size of government. Women are more likely to support spending for public health and redistributive policies but oppose military spending. In addition, we find little evidence that women favor investment in roads or transportation.

How do our results compare to previous studies on female policy makers in India and the United States? The limited effect on overall spending and a positive impact on public health spending is in line with evidence from state legislators in the United States (Rehavi, 2007). Unlike the Indian case, we do however not find that female policy makers affect education spending or investment in roads or transportation (Chattopadhyay and Duflo, 2004; Clots-Figueras, 2008a; 2008b). One potential 
explanation for this latter results is that political preferences of men and women shift with the level of economic development.

In addition to the political context, our study also differs from the existing literature along at least two other dimensions. In particular, we analyze political decision making in the electorate at large rather than the selected set of elected representatives alone. Due to the absence of incentives for strategic behavior, we measure gender gaps in a setting where policy makers vote according to their genuine political preferences.

Since politicians' own political preferences (ideology) have a stronger impact on political decisions than preferences of the electorate (see e.g. Levitt, 1996), we think that our results are informative for the impact of female policy makers in Europe more generally. Nevertheless, the more the candidate's positions are determined by voter preferences, the more we would expect the gender gap in observable political decisions to be reduced. From that perspective, our findings can be considered an upper bound of the effect for elected female policy makers.

However, we think that our study is highly relevant to understanding the impact of large-scale changes in political representation. Gender quotas propose a substantial increase in the political representation of women to, for example, 30 to 40 percent of parliamentary seats. Consequently, it is likely that gender quotas would alter the selection of elected female politicians in the direction of the general female population. More generally, gender quotas might reduce political competition and therefore increase the scope of policies where women politicians' can implement their own political preferences. In this view, our estimated gender gaps in policy-making complement earlier studies that focus on elected politicians.

\section{References}

[1] Adams, R. and D. Ferreira (2008), "Women in the Boardroom and their Impact on Governance 
and Performance," Journal of Financial Economics, forthcoming.

[2] Aidt, T.S., J. Duta and E. Loukoianova (2006), "Democracy comes to Europe: Franchise Extension and Fiscal Outcomes 1830-1938," European Economic Review, 50: 249-83.

[3] Aidt, T.S. and B. Dallal (2008), "Female Voting Power: The contribution of women's suffrage to the growh of social spending in Western Europe (1869-1960)," Public Choice, 134: 391-417.

[4] Alesina, A. and E. Ferrara (2005), "Preferences for redistribution in the land of opportunities," Journal of Public Economics, 89: 897-931.

[5] Chattopadhyay, R. and E. Duflo (2004), "Women as Policy Makers: Evidence from a Randomized Experiment in India," Econometrica, 72: 1409-1443.

[6] Clots-Figueras, I. (2008a), "Women in Politics. Evidence from the Indian States," Mimeo, Universidad Carlos III de Madrid.

[7] Clots-Figueras, I. (2008b), "Are Female Leaders Good for Education? Evidence from India," Mimeo, Universidad Carlos III de Madrid.

[8] Duflo, E. (2003), "Grandmothers and Granddaugthers: Old Age Pension and Intra-Household Allocation in South Africa," World Bank Economic Review, 17: 1-25.

[9] Edlund, L. and R. Pande (2002), "Why Have Women Become More Left-Wing? The Political Gender Gap and the Decline in Marriage," Quarterly Journal of Economics, 117: 917-61.

[10] Edlund, L., Haider L. and R. Pande (2005), "Unmarried Parenthood and Redistributive Politics," Journal of the European Economic Association, 3: 95-119.

[11] Fong, C. (2001), "Social preferences, self-interest and the demand for redistribution," Journal of Public Economics, 82: 225-246. 
[12] Funk, P. and C. Gathmann (2007), "What Women Want: Women Suffrage, Gender Gaps in Voter Preferences and Government Expenditures," Mimeo, Stanford University.

[13] Inglehart, R. and P. Norris (2003), Rising Tide: Gender Equality and Cultural Change around the World, Cambridge, UK.

[14] Longchamp, C. and U. Bieri (2001), "Frauen und Männer als Stimmbürger: Wie haben sie entschieden?," http://www.gfsbern.ch/gfs/gender.html.

[15] Lott, J.R. and L.W. Kenny (1999), "Did Women's Suffrage Change the Size and Scope of Government?" Journal of Political Economy, 107: 1163-98.

[16] Matsusaka, J.G. and N.M. McCarty (2001), "Political Resource Allocation: Benefits and Costs of Voter Initiatives", The Journal of Law, Economcis and Organization, 17: 413-448.

[17] Meltzer, A.H. and S.F. Richard (1981), "A Rational Theory of the Size of Government," Journal of Political Economy, 89, 914-27.

[18] Miller, G. (2008), "Women's Suffrage, Political Responsiveness, and Child Survival in American History," Quarterly Journal of Economics, 123: 1287-1327.

[19] Müller C. (1988), The Politics of the Gender Gap: The Social Construction of Political Influence. London.

[20] Niederle, M. and L. Vesterlund (2007), "Do Women Shy away from Competition? Do Men Compete too Much?," Quarterly Journal of Economics, 122: 1067-1101

[21] Norris, P. (1988), "The Gender Gap: A Cross-National Trend?", in: The Politics of the Gender Gap: The Social Construction of Political Influence, edited by C. Müller.

[22] Rehavi, M. (2007), "Sex and Politics: Do Female Legislators Affect State Spending?," Mimeo, University of California at Berkeley. 
[23] Shapiro, R. and H. Mahajan (1986), "Gender Differences in Policy Preferences: A Summary of Trends from the 1960's to the 1980's," Public Opinion Quarterly, 50: 42-61.

[24] Stutzer, A. and L. Kienast (2005), "Demokratische Beteiligung und Staatsausgaben: Die Auswirkungen des Frauenstimmrechts," Swiss Journal of Economics and Statistics, 141: 617650.

[25] The Economist (2008), "Women rising. Quotas to help women reach power are spreading," The Economist, 18. September 2008.

[26] Thomas, S. (1991), "The impact of Women on State Legislative Policies," Journal of Politics, 53: 958-76.

[27] Trechsel, A. and H. Kriesi (1996), "Switzerland: The Referendum and Initiative as a Centrepiece of the Political System," in: The Referendum Experience in Europe, edited by Gallagher and Uleri.

[28] Washinton, E. (2008) "Female Socialization: How Daughters Affect Their Legislator Fathers' Voting on Women's Issues," American Economic Review, 98: 311-332. 


\section{A Appendix: Description of the votes with the largest gender gaps}

\section{Reduction Tobacco Consumption (Initiative)}

Vote held November 28, 1993; Vote Nr. 404; Turnout: $45.5 \%$; Share-Yes: $25.5 \%$

Goal Initiative: To prohibit advertisement for tobacco. To use $1 \%$ of the revenues from taxing tobacco to educate about the health consequences of tobacco consumption.

\section{Equal Representation of Women in Federal Government (Initiative)}

Vote held March 12, 2000; Vote Nr. 461; Turnout: 42.2 \%; Share-Yes: $18 \%$

Goal Initiative: Adjust the stuffing policy of the federal government to guarantee equal chances for men and women.

No direct financial consequences indicated.

\section{Change in Marital Law (Referendum)}

Vote held September 22, 1985; Vote Nr. 336; Turnout: $41.1 \%$; Share-Yes: $54.7 \%$

Goal Law: Change the marital law to explicitly state that husbands and wives have equal rights and obligations. Housework and childcare are considered as a fulltime contribution to the family maintenance.

No financial consequences indicated.

\section{Against Racial Discrimination (Referendum)}

Vote held September 25, 1994; Vote Nr. 414; Turnout: 45.9 \%; Share-Yes: $54.6 \%$

Goal Law: Change of the Law (Civil law and Military law) to prosecute persons who engage actively in promoting discrimination based on race, ethnicity, or religion.

No financial consequences indicated.

\section{Against Subsidies for Corn Production (Referendum)}

Vote held September 25, 1994; Vote Nr. 413; Turnout: 45.5 \%; Share-Yes: $64.6 \%$

Goal Federal Resolution: To reduce the subsidies for corn production. Initially, the government bought corn from the Swiss corn produces at higher (than market) prices to maintain a high level of domestic production for situations of crises like wars. To the mills, the government sold at (cheaper) foreign prices, which involved substantial costs.

\section{Reduction of Alcohol Consumption (Initiative)}

Vote held November 28, 1993; Vote Nr. 403; Turnout: $45.5 \%$; Share-Yes: $25.3 \%$

Goal Initiative: Prohibit Advertisement for Alcohol.

Fiscal Consequences: Higher taxes on alcohol. 


\section{Protection of Rivers and Lakes (Initiative)}

Vote held Mai 17, 1992; Vote Nr. 381; Turnout: 39.2 \%; Share-Yes: $37.1 \%$

Goal Initiative: Protection of rivers and lakes, major objectives are the following: to protect human beings and animals, to secure the portable water supply, to protect the living space for flora and fauna, and to secure the water supply for agricultural purposes.

Financial consequences, as indicated in the election documents: Once the law takes place (1992), the average costs for the government will be around 100 million SF per year (in the beginning 170 mio. SF, at the end 40 mio. SF)

\section{For a Car free Sunday per Quarter (Initiative)}

Vote held Mai 18, 2003; Vote Nr. 498; Turnout: 49.8 \%; Share-Yes: $37.6 \%$

Goal Initiative: For the next four years, there should be one Sunday per season where private motorized vehicles are only permitted in exceptional circumstances (e.g. ambulances).

\section{For Abandoning Nuclear Energy (Initiative)}

Vote held September 23, 1990; Vote Nr. 365; Turnout: $40.4 \%$; Share-Yes: $47.1 \%$

Goal Initiative: No further implementation of nuclear plants

No fiscal major fiscal implications, potentially an increase unemployment in the nuclear sector.

\section{For Equal Rights of the Disabled (Initiative)}

Vote held Mai 18, 2003; Vote Nr. 500; Turnout: 49.7 \%; Share-Yes: $37.7 \%$

Goal Initiative: Equal rights for disabled people and abolishment of any sort of existing discrimination. Furthermore, where financially feasible, the entrances of public buildings and facilities should be made handicapped accessible.

Fiscal consequences in case of acceptance: Costs for reconstruction and renovation (2-4 mio. $\mathrm{SF}$ ). 10 mio. SF for the reconstruction of universities; further costs for infrastructure possible.

\section{Equal rights for Men and Women (Initiative)}

Vote held Juni 14, 1981; Vote Nr. 306; Turnout: 33.9 \%; Share-Yes: $60.3 \%$

Goal Initiative: To change Article 4 of the Constitution in the following way: Men and Women have equal rights and obligations within the family, must not be discriminated with respect to wages and have the right to equal treatment and chances in education, vocational training and to equal employment and promotion opportunities.

Financial consequences unclear. Costs could arise in the following areas - Federal government: social security, taxes, education, public servants - Canton: daycare, arbitrary duties in case of a breach against the required equality with respect to wages. Expenses are expected to be higher for Cantons than the government. 
Table 1: Summary Statistics, VOX-Data

\begin{tabular}{|c|c|c|c|c|c|}
\hline & & & & & T Statistic \\
\hline & Mean & Std. Dev & Mean & Std. Dev & Difference \\
\hline Demographics & & & & & \\
\hline Age & 48.39 & 16.38 & 49.98 & 17.41 & 14.92 \\
\hline Protestant & 0.47 & 0.50 & 0.47 & 0.50 & -1.08 \\
\hline Have Kids & 0.41 & 0.49 & 0.33 & 0.47 & -13.74 \\
\hline Single & 0.19 & 0.39 & 0.23 & 0.42 & 15.57 \\
\hline Married & 0.66 & 0.47 & 0.71 & 0.45 & 16.14 \\
\hline Divorced & 0.05 & 0.21 & 0.03 & 0.17 & -12.02 \\
\hline Education, Work and Income & & & & & \\
\hline Education: Compulsory & 0.19 & 0.40 & 0.10 & 0.30 & -44.52 \\
\hline Education: Apprentice/Spec Schools & 0.74 & 0.44 & 0.77 & 0.42 & 13.54 \\
\hline Education: University & 0.07 & 0.26 & 0.13 & 0.34 & 31.86 \\
\hline Employed & 0.51 & 0.50 & 0.69 & 0.46 & 57.72 \\
\hline Income & 1.76 & 0.82 & 2.21 & 1.06 & 13.34 \\
\hline House Ownership & 0.46 & 0.50 & 0.50 & 0.50 & 9.88 \\
\hline Knowledge Vote & & & & & \\
\hline Know Details Vote & 0.74 & 0.44 & 0.82 & 0.39 & 37.90 \\
\hline Region of Residence & & & & & \\
\hline Urban & 0.66 & 0.47 & 0.64 & 0.48 & -6.77 \\
\hline French- or Italian-Speaking Canton & 0.26 & 0.44 & 0.24 & 0.43 & -4.53 \\
\hline
\end{tabular}


Table 2: Federal Propositions with the Largest Gender Gap

\begin{tabular}{|c|c|c|c|}
\hline Title of Proposition & $\begin{array}{c}\text { Vote } \\
\text { Number }\end{array}$ & Year of Vote & $\begin{array}{c}\text { Gender Gap } \\
(\%)\end{array}$ \\
\hline Reduction of Tobacco Consumption & 404 & 1993 & 17.7 \\
\hline Equal Representation of Women in Federal Government & 461 & 2000 & 17.5 \\
\hline Change in Marital Law & 336 & 1985 & 17.0 \\
\hline Against Racial Discrimination & 414 & 1994 & 16.8 \\
\hline Against Subsidies for Corn Production & 413 & 1994 & 15.6 \\
\hline Reduction of Alcohol Consumption & 403 & 1993 & 15.5 \\
\hline For Protection of Rivers and Lakes & 381 & 1992 & 15.3 \\
\hline For a Car Free Sunday per Quarter & 498 & 2003 & 14.9 \\
\hline For Abandoning Nuclear Energy & 365 & 1990 & 14.7 \\
\hline For Equal Rights of the Disabled & 500 & 2003 & 14.6 \\
\hline Equal Rights of Men and Women & 306 & 1981 & 14.5 \\
\hline
\end{tabular}

Notes: The second column reports the official number of the vote and the third column the year the vote was held. The final column shows the gender gap, the percentage of women approving the proposition minus the percentage of men. Positive numbers imply that women were more supportive of the proposition than men.

Source: VOX Surveys, 1981-2003, Sample of Voters. 
Table 3: Titles of Federal Propositions by Policy Area

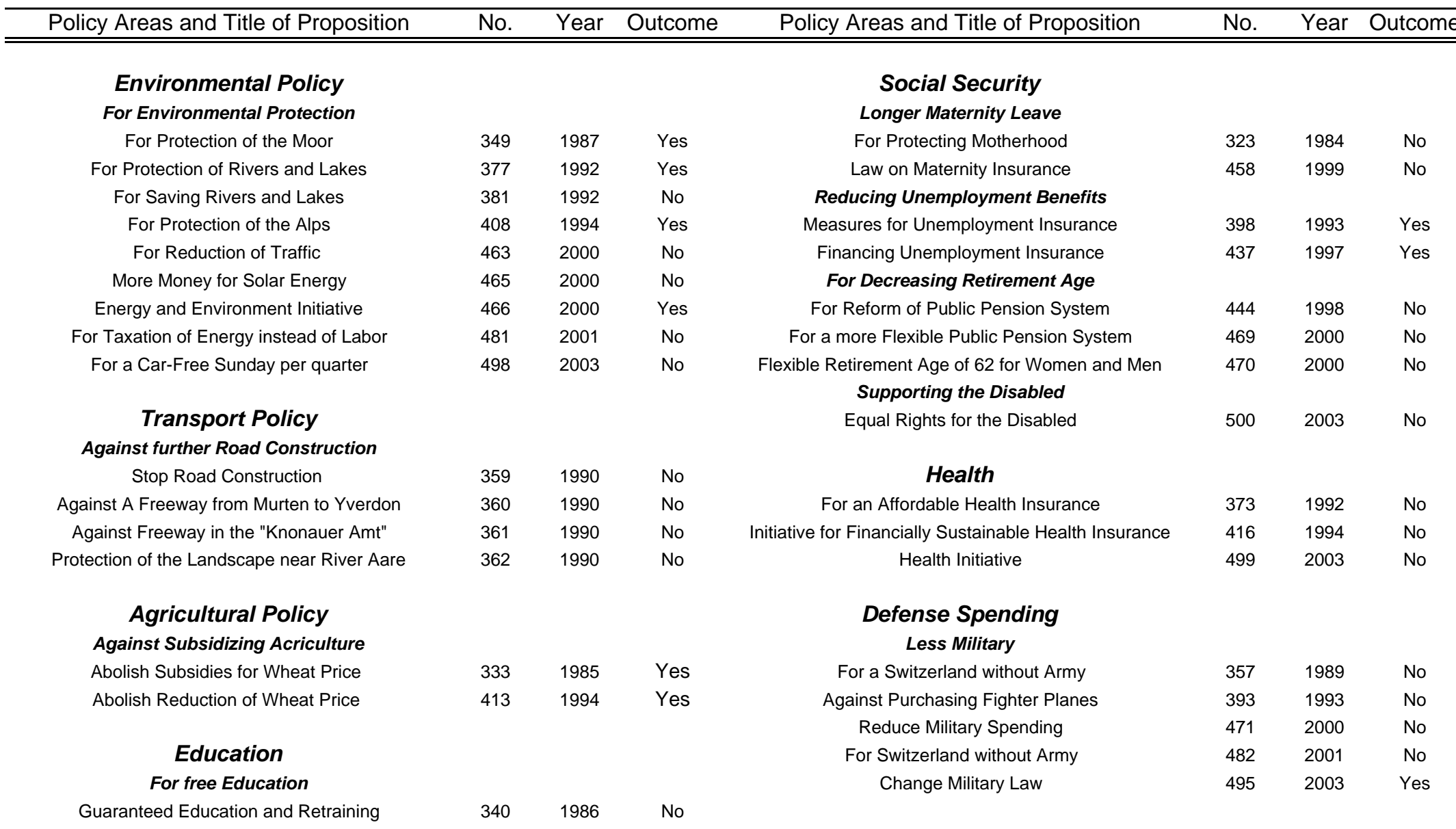

Notes: The table reports all federal votes between 1981 and 2003, which can be classified into one of the following seven categories: Environmental and Nuclear Policy, Transportation, Agricultural Policy, Social Security, Education, Health and Military Policy. Source: Federal Administration of Switzerland; online available at http://www.admin.ch/ch/d/pore/va/index.html 
Table 4: Voting Behavior of Men and Women in Federal Propositions

\begin{tabular}{|c|c|c|c|c|c|c|c|c|c|c|}
\hline & $\begin{array}{c}\text { Environment } \\
\text { Protection } \\
\text { of the } \\
\text { Environment }\end{array}$ & $\begin{array}{c}\text { Transport } \\
\text { Against } \\
\text { further Road } \\
\text { Construction }\end{array}$ & $\begin{array}{l}\text { Military } \\
\text { Less } \\
\text { Military }\end{array}$ & $\begin{array}{l}\text { Agriculture } \\
\text { Against } \\
\text { Subsidies for } \\
\text { Agriculture } \\
\end{array}$ & $\begin{array}{l}\text { Education } \\
\text { Free } \\
\text { Education }\end{array}$ & $\begin{array}{c}\text { Health } \\
\text { Subsidies } \\
\text { Health } \\
\text { Insurance } \\
\end{array}$ & $\begin{array}{c}\text { Reduce } \\
\text { Unemployment } \\
\text { Benefits } \\
\end{array}$ & $\begin{array}{c}\text { Welfar } \\
\text { Decrease } \\
\text { Retirement } \\
\text { Age } \\
\end{array}$ & $\begin{array}{l}\text { Support } \\
\text { for the } \\
\text { Disabled } \\
\end{array}$ & $\begin{array}{c}\text { Longer } \\
\text { Maternity } \\
\text { Leave } \\
\end{array}$ \\
\hline Female Dummy & $\begin{array}{c}0,084 \\
(0.015)^{\star \star \star}\end{array}$ & $\begin{array}{c}0,045 \\
(0.022)^{\star \star}\end{array}$ & $\begin{array}{c}0,043 \\
(0.023)^{\star \star}\end{array}$ & $\begin{array}{c}0,091 \\
(0.035)^{\star \star}\end{array}$ & $\begin{array}{c}0.068 \\
(0.059)\end{array}$ & $\begin{array}{c}0.065 \\
(0.029)^{\star \star}\end{array}$ & $\begin{array}{c}-0,054 \\
(0.032)^{\star}\end{array}$ & $\begin{array}{c}0.063 \\
(0.019)^{\star \star \star}\end{array}$ & $\begin{array}{c}0,151 \\
(0.045)^{\star \star \star}\end{array}$ & $\begin{array}{c}0,06 \\
(0.025)^{\star \star}\end{array}$ \\
\hline Controls for Region & YES & YES & YES & YES & YES & YES & YES & YES & YES & YES \\
\hline Year and Canton FE & YES & YES & YES & YES & YES & YES & YES & YES & YES & YES \\
\hline Observations & 5022 & 1994 & 2164 & 757 & 258 & 1071 & 992 & 2588 & 513 & 1509 \\
\hline Log-Likelihood & -3151.00 & -1204.42 & -1283.06 & -461.49 & -148.10 & -609.48 & -538.50 & -1563.91 & -332.07 & -923.76 \\
\hline
\end{tabular}

Notes: The table reports estimates from a probit model with marginal coefficients being displayed. The dependent variable is the voting decision, which is equal to one if the respondent supported the proposition and zero otherwise for the propositions shown in the column header. The table reports the coefficient on the female dummy. All specifications include canton and year fixed effects. Controls for the region of residence, such as language and urban area are included as well. Robust standard errors are reported in parentheses. Coefficients with *** are significant at the 1 percent level, while those with ** $\left(^{*}\right)$ are significant at the 5 (10) percent level. The last row reports the value of the log-likelihood function. 
Table 5: Voting Behavior of Men and Women in Federal Propositions

\begin{tabular}{|c|c|c|c|c|c|c|c|c|c|c|}
\hline & $\begin{array}{l}\text { Environment } \\
\text { Protection } \\
\text { of the } \\
\text { Environment } \\
\end{array}$ & $\begin{array}{c}\text { Transport } \\
\text { Against } \\
\text { further Road } \\
\text { Construction } \\
\end{array}$ & $\begin{array}{l}\text { Military } \\
\text { Less } \\
\text { Military }\end{array}$ & $\begin{array}{l}\text { Agriculture } \\
\text { Against } \\
\text { Subsidies for } \\
\text { Agriculture } \\
\end{array}$ & $\begin{array}{l}\text { Education } \\
\text { Free } \\
\text { Education }\end{array}$ & $\begin{array}{c}\text { Health } \\
\text { Subsidies } \\
\text { Health } \\
\text { Insurance } \\
\end{array}$ & $\begin{array}{c}\text { Reduce } \\
\text { Unemployment } \\
\text { Benefits } \\
\end{array}$ & $\begin{array}{c}\text { Welfare } \\
\text { Decrease } \\
\text { Retirement } \\
\text { Age } \\
\end{array}$ & $\begin{array}{l}\text { Support } \\
\text { for the } \\
\text { Disabled }\end{array}$ & $\begin{array}{c}\text { Longer } \\
\text { Maternity } \\
\text { Leave } \\
\end{array}$ \\
\hline Female Dummy & $\begin{array}{c}0.074 \\
(0.015)^{\star \star \star}\end{array}$ & $\begin{array}{c}0.030 \\
(0.024)\end{array}$ & $\begin{array}{c}0.047 \\
(0.025)^{\star}\end{array}$ & $\begin{array}{c}0.107 \\
(0.038)^{\star \star \star}\end{array}$ & $\begin{array}{c}0.017 \\
(0.068)\end{array}$ & $\begin{array}{c}0.040 \\
(0.032)\end{array}$ & $\begin{array}{l}-0.043 \\
(0.035)\end{array}$ & $\begin{array}{c}0.053 \\
(0.020)^{\star \star \star}\end{array}$ & $\begin{array}{c}0.134 \\
(0.047)^{\star \star \star}\end{array}$ & $\begin{array}{c}0.049 \\
(0.028)^{\star}\end{array}$ \\
\hline University Education & $\begin{array}{c}0.126 \\
(0.024)^{\star \star \star}\end{array}$ & $\begin{array}{c}0.073 \\
(0.040)^{\star}\end{array}$ & $\begin{array}{c}0.127 \\
(0.040)^{\star \star \star}\end{array}$ & $\begin{array}{c}0.191 \\
(0.062)^{\star \star \star}\end{array}$ & & $\begin{array}{c}0.035 \\
(0.053)\end{array}$ & $\begin{array}{c}0.058 \\
(0.046)\end{array}$ & $\begin{array}{l}-0.006 \\
(0.032)\end{array}$ & $\begin{array}{c}0.028 \\
(0.069)\end{array}$ & $\begin{array}{c}0.216 \\
(0.053)^{\star \star \star}\end{array}$ \\
\hline Married & $\begin{array}{l}-0.017 \\
(0.017)\end{array}$ & $\begin{array}{c}-0.151 \\
(0.026)^{\star \star \star}\end{array}$ & $\begin{array}{l}-0.022 \\
(0.027)\end{array}$ & $\begin{array}{l}-0.008 \\
(0.043)\end{array}$ & $\begin{array}{l}-0.034 \\
(0.066)\end{array}$ & $\begin{array}{l}-0.010 \\
(0.034)\end{array}$ & $\begin{array}{c}-0.065 \\
(0.037)^{\star}\end{array}$ & $\begin{array}{l}-0.007 \\
(0.022)\end{array}$ & $\begin{array}{l}-0.045 \\
(0.053)\end{array}$ & $\begin{array}{l}-0.045 \\
(0.030)\end{array}$ \\
\hline Houseowner & $\begin{array}{c}-0.073 \\
(0.016)^{\star \star \star}\end{array}$ & $\begin{array}{c}-0.040 \\
(0.023)^{\star}\end{array}$ & $\begin{array}{c}-0.090 \\
(0.025)^{\star \star \star}\end{array}$ & $\begin{array}{c}0.029 \\
(0.042)\end{array}$ & $\begin{array}{c}-0.148 \\
(0.065)^{\star \star}\end{array}$ & $\begin{array}{c}-0.079 \\
(0.033)^{\star \star}\end{array}$ & $\begin{array}{c}0.074 \\
(0.035)^{\star \star}\end{array}$ & $\begin{array}{c}-0.076 \\
(0.021)^{\star \star \star}\end{array}$ & $\begin{array}{c}-0.102 \\
(0.051)^{\star \star}\end{array}$ & $\begin{array}{l}-0.034 \\
(0.029)\end{array}$ \\
\hline Employed & $\begin{array}{c}-0.030 \\
(0.018)^{\star}\end{array}$ & $\begin{array}{l}-0.028 \\
(0.026)\end{array}$ & $\begin{array}{c}0.057 \\
(0.030)^{\star}\end{array}$ & $\begin{array}{l}-0.061 \\
(0.042)\end{array}$ & $\begin{array}{c}-0.160 \\
(0.076)^{\star \star}\end{array}$ & $\begin{array}{l}-0.019 \\
(0.036)\end{array}$ & $\begin{array}{c}0.029 \\
(0.039)\end{array}$ & $\begin{array}{c}0.023 \\
(0.024)\end{array}$ & $\begin{array}{l}-0.045 \\
(0.055)\end{array}$ & $\begin{array}{l}-0.016 \\
(0.031)\end{array}$ \\
\hline Age & $\begin{array}{c}-0.004 \\
(0.001)^{\star \star \star}\end{array}$ & $\begin{array}{c}-0.002 \\
(0.001)^{\star \star}\end{array}$ & $\begin{array}{c}-0.005 \\
(0.001)^{\star \star \star}\end{array}$ & $\begin{array}{c}0.001 \\
(0.001)\end{array}$ & $\begin{array}{l}-0.000 \\
(0.002)\end{array}$ & $\begin{array}{l}-0.000 \\
(0.001)\end{array}$ & $\begin{array}{c}0.004 \\
(0.001)^{\star \star \star}\end{array}$ & $\begin{array}{c}-0.002 \\
(0.001)^{\star \star \star}\end{array}$ & $\begin{array}{l}-0.001 \\
(0.002)\end{array}$ & $\begin{array}{c}-0.005 \\
(0.001)^{\star \star \star}\end{array}$ \\
\hline Controls for Region & YES & YES & YES & YES & YES & YES & YES & YES & YES & YES \\
\hline Year and Canton FE & YES & YES & YES & YES & YES & YES & YES & YES & YES & YES \\
\hline Observations & 4865 & 1969 & 2100 & 697 & 254 & 960 & 958 & 2513 & 508 & 1456 \\
\hline Log-Likelihood & -2991.83 & -1157.50 & -1187.68 & -420.30 & -139.84 & -530.00 & -511.60 & -1498.67 & -324.30 & -854.89 \\
\hline
\end{tabular}

Notes: The table reports estimates from a probit model with marginal coefficients being displayed. The dependent variable is the voting decision, which is equal to one if the respondent supported the proposition and zero otherwise for the propositions shown in the column header. The table reports the coefficient on the female dummy. All specifications include canton and year fixed effects. Controls for the region of residence, such as language and urban area as well as socio-demographics are included as well (all controls except age are binary variables). Robust standard errors are reported in parentheses. Coefficients with ${ }^{\star *}$ are significant at the 1 percent level, while those with $\left.{ }^{* *}{ }^{*}\right)$ are significant at the $5(10)$ percent level. The last row reports the value of the log-likelihood function. 
Table 6: Voting Behavior of Men and Women in Federal Propositions

\begin{tabular}{|c|c|c|c|c|c|c|c|c|c|c|}
\hline & $\begin{array}{c}\text { Environment } \\
\text { Protection } \\
\text { of the } \\
\text { Environment }\end{array}$ & $\begin{array}{c}\text { Transport } \\
\text { Against } \\
\text { further Road } \\
\text { Construction }\end{array}$ & $\begin{array}{l}\text { Military } \\
\text { Less } \\
\text { Military }\end{array}$ & $\begin{array}{l}\text { Agriculture } \\
\text { Against } \\
\text { Subsidies for } \\
\text { Agriculture }\end{array}$ & $\begin{array}{l}\text { Education } \\
\text { Free } \\
\text { Education }\end{array}$ & $\begin{array}{c}\text { Health } \\
\text { Subsidies } \\
\text { Health } \\
\text { Insurance } \\
\end{array}$ & $\begin{array}{c}\text { Reduce } \\
\text { Unemployment } \\
\text { Benefits } \\
\end{array}$ & $\begin{array}{c}\text { Welfar } \\
\text { Decrease } \\
\text { Retirement } \\
\text { Age } \\
\end{array}$ & $\begin{array}{l}\text { Support } \\
\text { for the } \\
\text { Disabled }\end{array}$ & $\begin{array}{c}\text { Longer } \\
\text { Maternity } \\
\text { Leave }\end{array}$ \\
\hline Female Dummy & $\begin{array}{c}0.072 \\
(0.016)^{\star \star \star}\end{array}$ & $\begin{array}{c}0.055 \\
(0.025)^{\star \star}\end{array}$ & $\begin{array}{c}0.044 \\
(0.026)^{\star}\end{array}$ & $\begin{array}{c}0.096 \\
(0.039)^{\star \star}\end{array}$ & $\begin{array}{c}0.017 \\
(0.068)\end{array}$ & $\begin{array}{c}0.052 \\
(0.033)\end{array}$ & $\begin{array}{l}-0.043 \\
(0.037)\end{array}$ & $\begin{array}{c}0.052 \\
(0.022)^{\star \star}\end{array}$ & $\begin{array}{c}0.115 \\
(0.050)^{\star \star}\end{array}$ & $\begin{array}{c}0.044 \\
(0.029)\end{array}$ \\
\hline Female*University & $\begin{array}{c}0.013 \\
(0.050)\end{array}$ & $\begin{array}{c}-0.214 \\
(0.049)^{\star \star \star}\end{array}$ & $\begin{array}{c}0.032 \\
(0.086)\end{array}$ & $\begin{array}{c}0.246 \\
(0.085)^{\star \star \star}\end{array}$ & & $\begin{array}{l}-0.118 \\
(0.078)\end{array}$ & $\begin{array}{c}-0.007 \\
(0.104)\end{array}$ & $\begin{array}{c}0.015 \\
(0.066)\end{array}$ & $\begin{array}{c}0.166 \\
(0.131)\end{array}$ & $\begin{array}{c}0.067 \\
(0.109)\end{array}$ \\
\hline University Education & $\begin{array}{c}0.121 \\
(0.029)^{\star \star \star}\end{array}$ & $\begin{array}{c}0.153 \\
(0.047)^{\star \star \star}\end{array}$ & $\begin{array}{c}0.116 \\
(0.048)^{\star \star}\end{array}$ & $\begin{array}{c}0.132 \\
(0.087)\end{array}$ & & $\begin{array}{c}0.087 \\
(0.067)\end{array}$ & $\begin{array}{c}0.060 \\
(0.055)\end{array}$ & $\begin{array}{l}-0.011 \\
(0.040)\end{array}$ & $\begin{array}{l}-0.034 \\
(0.091)\end{array}$ & $\begin{array}{c}0.192 \\
(0.066)^{\star \star \star}\end{array}$ \\
\hline Married & $\begin{array}{l}-0.017 \\
(0.017)\end{array}$ & $\begin{array}{c}-0.152 \\
(0.026)^{\star \star \star}\end{array}$ & $\begin{array}{l}-0.022 \\
(0.027)\end{array}$ & $\begin{array}{l}-0.011 \\
(0.043)\end{array}$ & $\begin{array}{c}-0.034 \\
(0.066)\end{array}$ & $\begin{array}{l}-0.012 \\
(0.034)\end{array}$ & $\begin{array}{c}-0.065 \\
(0.037)^{\star}\end{array}$ & $\begin{array}{c}-0.007 \\
(0.022)\end{array}$ & $\begin{array}{l}-0.047 \\
(0.053)\end{array}$ & $\begin{array}{c}-0.046 \\
(0.030)\end{array}$ \\
\hline Houseowner & $\begin{array}{c}-0.073 \\
(0.016)^{\star \star \star}\end{array}$ & $\begin{array}{c}-0.041 \\
(0.023)^{\star}\end{array}$ & $\begin{array}{c}-0.090 \\
(0.025)^{\star \star \star}\end{array}$ & $\begin{array}{c}0.031 \\
(0.041)\end{array}$ & $\begin{array}{c}-0.148 \\
(0.065)^{\star \star}\end{array}$ & $\begin{array}{c}-0.081 \\
(0.033)^{\star *}\end{array}$ & $\begin{array}{c}0.074 \\
(0.035)^{\star *}\end{array}$ & $\begin{array}{c}-0.076 \\
(0.021)^{\star \star \star}\end{array}$ & $\begin{array}{c}-0.098 \\
(0.051)^{\star}\end{array}$ & $\begin{array}{l}-0.034 \\
(0.029)\end{array}$ \\
\hline Employed & $\begin{array}{c}-0.030 \\
(0.018)^{\star}\end{array}$ & $\begin{array}{c}-0.021 \\
(0.026)\end{array}$ & $\begin{array}{c}0.057 \\
(0.030)^{\star}\end{array}$ & $\begin{array}{l}-0.064 \\
(0.042)\end{array}$ & $\begin{array}{c}-0.160 \\
(0.076)^{\star \star}\end{array}$ & $\begin{array}{c}-0.017 \\
(0.036)\end{array}$ & $\begin{array}{c}0.029 \\
(0.039)\end{array}$ & $\begin{array}{c}0.023 \\
(0.024)\end{array}$ & $\begin{array}{c}-0.043 \\
(0.055)\end{array}$ & $\begin{array}{l}-0.016 \\
(0.031)\end{array}$ \\
\hline Age & $\begin{array}{c}-0.004 \\
(0.001)^{\star \star \star}\end{array}$ & $\begin{array}{c}-0.002 \\
(0.001)^{\star \star}\end{array}$ & $\begin{array}{c}-0.005 \\
(0.001)^{\star \star \star}\end{array}$ & $\begin{array}{c}0.001 \\
(0.001)\end{array}$ & $\begin{array}{l}-0.000 \\
(0.002)\end{array}$ & $\begin{array}{l}-0.000 \\
(0.001)\end{array}$ & $\begin{array}{c}0.004 \\
(0.001)^{\star \star \star}\end{array}$ & $\begin{array}{c}-0.002 \\
(0.001)^{\star \star \star}\end{array}$ & $\begin{array}{l}-0.001 \\
(0.002)\end{array}$ & $\begin{array}{c}-0.005 \\
(0.001)^{\star \star \star}\end{array}$ \\
\hline Controls for Region & YES & YES & YES & YES & YES & YES & YES & YES & YES & YES \\
\hline Year and Canton FE & YES & YES & YES & YES & YES & YES & YES & YES & YES & YES \\
\hline Observations & 4869 & 1969 & 2104 & 716 & 254 & 963 & 963 & 2516 & 508 & 1472 \\
\hline Log-Likelihood & -2991.79 & -1152.45 & -1187.60 & -419.29 & -139.84 & -529.20 & -511.60 & -1498.65 & -323.65 & -854.69 \\
\hline
\end{tabular}

Notes: The table reports estimates from a probit model with marginal coefficients being displayed. The dependent variable is the voting decision, which is equal to one if the respondent supported the proposition and zero otherwise for the propositions shown in the column header. The table reports the coefficient on the female dummy. All specifications include canton and year fixed effects. Controls for the region of reside parentheses. Coefficients with ${ }^{* * *}$ are significant at the 1 percent level, while those with ** $\left(^{*}\right)$ are significant at the 5 (10) percent level. The last row reports the value of the log-likelihood function. 
Table 7: Support for Higher Expenditures in Federal Propositions

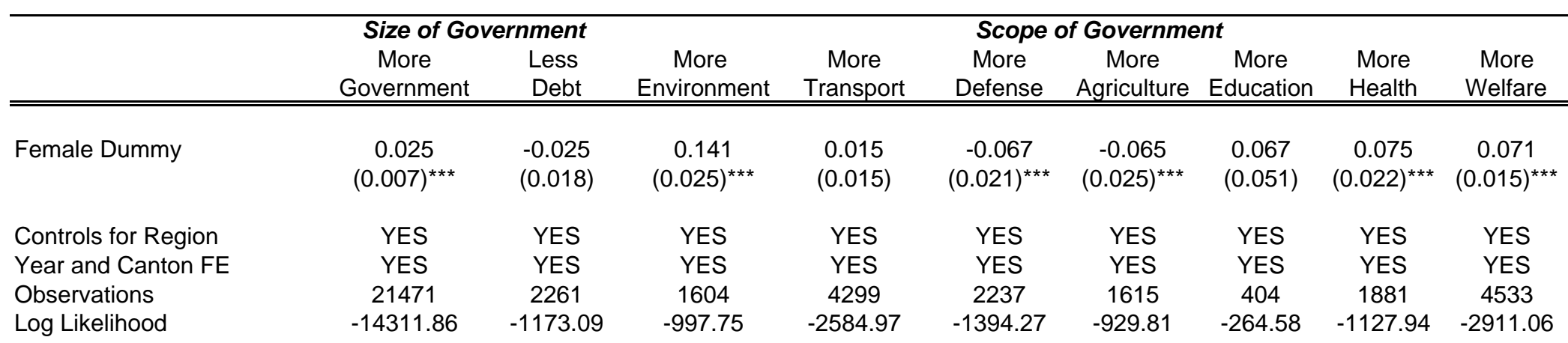

Notes: The table reports the marginal effects from a probit model whether the respondent supported a proposition, which would have increased government spending in the respective policy area or opposed it. The classification of the financial consequences of the propositions is based on the official documents distributed by the Swiss government before the vote (see main text). The Appendix shows a list of the federal propositions underlying each column. The table resports the coefficient on the female dummy variable in each row. The specifications are the same as in Table 4. See notes to Table 4 for further details. Robust standard errors are reported in parentheses. 
Table 8: Support for Higher Expenditures in Federal Propositions

\begin{tabular}{|c|c|c|c|c|c|c|c|c|c|}
\hline & \multicolumn{2}{|c|}{ Size of Government } & \multicolumn{7}{|c|}{ Scope of Government } \\
\hline & $\begin{array}{c}\text { More } \\
\text { Government } \\
\end{array}$ & $\begin{array}{c}\text { Less } \\
\text { Debt } \\
\end{array}$ & $\begin{array}{c}\text { More } \\
\text { Environment } \\
\end{array}$ & $\begin{array}{c}\text { More } \\
\text { Transport } \\
\end{array}$ & $\begin{array}{c}\text { More } \\
\text { Defense } \\
\end{array}$ & $\begin{array}{c}\text { More } \\
\text { Agriculture } \\
\end{array}$ & $\begin{array}{c}\text { More } \\
\text { Education } \\
\end{array}$ & $\begin{array}{l}\text { More } \\
\text { Health } \\
\end{array}$ & $\begin{array}{c}\text { More } \\
\text { Welfare } \\
\end{array}$ \\
\hline Female Dummy & $\begin{array}{c}0.022 \\
(0.007)^{\star \star \star}\end{array}$ & $\begin{array}{l}-0.029 \\
(0.019)\end{array}$ & $\begin{array}{c}0.093 \\
(0.027)^{\star \star \star}\end{array}$ & $\begin{array}{c}0.018 \\
(0.016)\end{array}$ & $\begin{array}{c}-0.062 \\
(0.023)^{\star \star \star}\end{array}$ & $\begin{array}{c}-0.071 \\
(0.026)^{\star \star \star}\end{array}$ & $\begin{array}{c}0.122 \\
(0.057)^{\star \star}\end{array}$ & $\begin{array}{c}0.063 \\
(0.025)^{\star \star}\end{array}$ & $\begin{array}{c}0.063 \\
(0.016)^{\star \star \star}\end{array}$ \\
\hline University Education & $\begin{array}{c}0.136 \\
(0.012)^{\star \star \star}\end{array}$ & $\begin{array}{l}-0.014 \\
(0.033)\end{array}$ & $\begin{array}{l}-0.048 \\
(0.044)\end{array}$ & $\begin{array}{c}0.193 \\
(0.020)^{\star \star \star}\end{array}$ & $\begin{array}{c}-0.098 \\
(0.037)^{\star \star \star}\end{array}$ & $\begin{array}{c}-0.103 \\
(0.043)^{\star \star}\end{array}$ & $\begin{array}{c}0.151 \\
(0.102)\end{array}$ & $\begin{array}{c}0.116 \\
(0.044)^{\star \star \star *}\end{array}$ & $\begin{array}{l}-0.023 \\
(0.024)\end{array}$ \\
\hline Married & $\begin{array}{c}-0.025 \\
(0.008)^{\star \star \star}\end{array}$ & $\begin{array}{c}0.013 \\
(0.021)\end{array}$ & $\begin{array}{l}-0.037 \\
(0.030)\end{array}$ & $\begin{array}{l}-0.028 \\
(0.017)\end{array}$ & $\begin{array}{l}-0.001 \\
(0.024)\end{array}$ & $\begin{array}{l}-0.016 \\
(0.029)\end{array}$ & $\begin{array}{l}-0.032 \\
(0.062)\end{array}$ & $\begin{array}{l}-0.010 \\
(0.026)\end{array}$ & $\begin{array}{c}0.000 \\
(0.017)\end{array}$ \\
\hline Houseowner & $\begin{array}{c}-0.029 \\
(0.008)^{\star \star \star}\end{array}$ & $\begin{array}{c}0.032 \\
(0.020)\end{array}$ & $\begin{array}{c}-0.091 \\
(0.029)^{\star \star \star}\end{array}$ & $\begin{array}{l}-0.017 \\
(0.016)\end{array}$ & $\begin{array}{c}0.071 \\
(0.023)^{\star \star \star}\end{array}$ & $\begin{array}{c}0.008 \\
(0.028)\end{array}$ & $\begin{array}{c}-0.171 \\
(0.060)^{\star \star \star}\end{array}$ & $\begin{array}{c}-0.066 \\
(0.025)^{\star \star \star}\end{array}$ & $\begin{array}{c}-0.089 \\
(0.016)^{\star \star \star}\end{array}$ \\
\hline Employed & $\begin{array}{c}-0.030 \\
(0.008)^{\star \star \star}\end{array}$ & $\begin{array}{c}-0.057 \\
(0.021)^{\star \star \star}\end{array}$ & $\begin{array}{c}-0.065 \\
(0.030)^{\star \star}\end{array}$ & $\begin{array}{c}-0.052 \\
(0.018)^{\star \star \star}\end{array}$ & $\begin{array}{c}0.016 \\
(0.027)\end{array}$ & $\begin{array}{c}0.028 \\
(0.029)\end{array}$ & $\begin{array}{c}0.119 \\
(0.061)^{\star}\end{array}$ & $\begin{array}{l}-0.025 \\
(0.027)\end{array}$ & $\begin{array}{c}0.013 \\
(0.019)\end{array}$ \\
\hline Age & $\begin{array}{l}-0.000 \\
(0.000)\end{array}$ & $\begin{array}{c}0.001 \\
(0.001)\end{array}$ & $\begin{array}{c}-0.005 \\
(0.001)^{\star \star \star \star}\end{array}$ & $\begin{array}{c}0.002 \\
(0.001)^{\star \star \star}\end{array}$ & $\begin{array}{c}0.007 \\
(0.001)^{\star \star \star}\end{array}$ & $\begin{array}{c}0.000 \\
(0.001)\end{array}$ & $\begin{array}{c}0.002 \\
(0.002)\end{array}$ & $\begin{array}{l}-0.001 \\
(0.001)\end{array}$ & $\begin{array}{c}-0.003 \\
(0.001)^{\star \star \star}\end{array}$ \\
\hline Controls for Region & YES & YES & YES & YES & YES & YES & YES & YES & YES \\
\hline Year and Canton FE & YES & YES & YES & YES & YES & YES & YES & YES & YES \\
\hline Observations & 20591 & 2178 & 1533 & 4120 & 2162 & 1541 & 387 & 1735 & 4439 \\
\hline Log Likelihood & -13646.55 & -1115.29 & -922.69 & -2433.62 & -1285.77 & -883.86 & -246.11 & -1016.35 & -2810.43 \\
\hline
\end{tabular}

Notes: The table reports the marginal effects from a probit model whether the respondent supported a proposition, which would have increased government spending in the respective policy area or opposed it. The classification of the financial consequences of the propositions is based on the official documents distributed by the Swiss government before the vote (see main text). The Appendix shows a list of the federal propositions underlying each column. The table resports the coefficient on the female dummy variable in each row. The controls are the same as in Table 5 . Robust standard errors are reported in parentheses. 
Table 9: Robustness

\begin{tabular}{|c|c|c|c|c|c|c|c|c|c|}
\hline & \multicolumn{2}{|c|}{ Size of Government } & \multicolumn{7}{|c|}{ Scope of Government } \\
\hline & $\begin{array}{c}\text { More } \\
\text { Government } \\
\end{array}$ & $\begin{array}{c}\text { Less } \\
\text { Debt } \\
\end{array}$ & $\begin{array}{c}\text { More } \\
\text { Environment } \\
\end{array}$ & $\begin{array}{c}\text { More } \\
\text { Transport } \\
\end{array}$ & $\begin{array}{c}\text { More } \\
\text { Defense } \\
\end{array}$ & $\begin{array}{c}\text { More } \\
\text { Agriculture } \\
\end{array}$ & $\begin{array}{c}\text { More } \\
\text { Education } \\
\end{array}$ & $\begin{array}{l}\text { More } \\
\text { Health } \\
\end{array}$ & $\begin{array}{c}\text { More } \\
\text { Welfare } \\
\end{array}$ \\
\hline Female Dummy & $\begin{array}{c}0.022 \\
(0.007)^{\star \star \star}\end{array}$ & $\begin{array}{l}-0.029 \\
(0.019)\end{array}$ & $\begin{array}{c}0.093 \\
(0.027)^{\star \star \star}\end{array}$ & $\begin{array}{c}0.018 \\
(0.016)\end{array}$ & $\begin{array}{c}-0.062 \\
(0.023)^{\star \star \star}\end{array}$ & $\begin{array}{c}-0.071 \\
(0.026)^{\star \star \star}\end{array}$ & $\begin{array}{c}0.122 \\
(0.057)^{\star \star}\end{array}$ & $\begin{array}{c}0.063 \\
(0.025)^{\star *}\end{array}$ & $\begin{array}{c}0.063 \\
(0.016)^{\star \star \star}\end{array}$ \\
\hline \# Observations & 20591 & 2178 & 1533 & 4120 & 2162 & 1541 & 387 & 1735 & 4439 \\
\hline \multicolumn{10}{|l|}{ Specification Householdincome } \\
\hline $\begin{array}{l}\text { Female Dummy (Baseline) } \\
\text { Female Dummy + Income }\end{array}$ & $\begin{array}{l}0.035 \\
(0.012)^{\star \star \star} \\
0.036 \\
(0.012)^{\star \star \star}\end{array}$ & $\begin{array}{l}-0.040 \\
(0.023)^{*} \\
-0.039 \\
(0.023)^{\star}\end{array}$ & & $\begin{array}{c}0.002 \\
(0.033) \\
0.000 \\
(0.033)\end{array}$ & $\begin{array}{l}-0.063 \\
(0.032)^{\star *} \\
-0.064 \\
(0.032)^{\star \star}\end{array}$ & $\begin{array}{l}-0.054 \\
(0.036) \\
-0.050 \\
(0.036)\end{array}$ & & $\begin{array}{c}0.055 \\
(0.041) \\
0.054 \\
(0.041)\end{array}$ & $\begin{array}{c}0.072 \\
(0.018)^{\star \star \star} \\
0.071 \\
(0.018)^{\star \star \star}\end{array}$ \\
\hline \# Observations & 8148 & 1643 & & 962 & 986 & 677 & & 355 & 3558 \\
\hline \multicolumn{10}{|l|}{ Specification Knowledge Vote } \\
\hline $\begin{array}{l}\text { Female Dummy (Baseline) } \\
\text { Female Dummy + Knowledge Vote }\end{array}$ & $\begin{array}{l}0.026 \\
(0.008)^{\star * \star} \\
0.027 \\
(0.008)^{\star * *}\end{array}$ & $\begin{array}{l}-0.030 \\
(0.020) \\
-0.029 \\
(0.020)\end{array}$ & $\begin{array}{l}0.093 \\
(0.029)^{\star \star \star} \\
0.093 \\
(0.029)^{\star \star \star}\end{array}$ & $\begin{array}{c}0.023 \\
(0.016) \\
0.023 \\
(0.016)\end{array}$ & $\begin{array}{l}-0.060 \\
(0.023)^{\star \star \star} \\
-0.059 \\
(0.023)^{\star \star \star}\end{array}$ & $\begin{array}{l}-0.080 \\
(0.027)^{\star \star \star} \\
-0.085 \\
(0.027)^{\star \star \star}\end{array}$ & $\begin{array}{c}0.133 \\
(0.064)^{* *} \\
0.119 \\
(0.066)^{*}\end{array}$ & $\begin{array}{c}0.059 \\
(0.026)^{\star *} \\
0.059 \\
(0.026)^{\star *}\end{array}$ & $\begin{array}{c}0.064 \\
(0.016)^{\star * \star} \\
0.065 \\
(0.016)^{\star * \star}\end{array}$ \\
\hline $\begin{array}{l}\text { \# Observations } \\
\text { Specification Kids }\end{array}$ & 19456 & 1894 & 1413 & 3931 & 2126 & 1461 & 320 & 1624 & 4144 \\
\hline $\begin{array}{l}\text { Female Dummy (Baseline) } \\
\text { Female Dummy + Kids }\end{array}$ & $\begin{array}{c}0.019 \\
(0.013) \\
0.020 \\
(0.013)\end{array}$ & & $\begin{array}{c}0.094 \\
(0.027)^{\star \star \star} \\
0.094 \\
(0.027)^{\star \star \star}\end{array}$ & $\begin{array}{c}0.028 \\
(0.027) \\
0.030 \\
(0.027)\end{array}$ & $\begin{array}{l}-0.038 \\
(0.060) \\
-0.041 \\
(0.060)\end{array}$ & $\begin{array}{l}-0.068 \\
(0.054) \\
-0.062 \\
(0.054)\end{array}$ & & $\begin{array}{c}0.095 \\
(0.034)^{\star * *} \\
0.096 \\
(0.034)^{\star * *}\end{array}$ & \\
\hline \# Observations & 7102 & & 1528 & 1535 & 350 & 436 & & 1017 & \\
\hline
\end{tabular}

Notes: The table reports the marginal effects from a probit model whether the respondent supported (or not) a proposition, which would have increased government spending in the respective policy area. The table reports the coefficient on the female dummy variable in each row. The first row replicates the results of table 8, with controls for education, marital status, houseownership, employement status and age. The specification "Household lncome" estimates the female dummy for observations with household-income reported. The first row displays regressions without household income, but again controls for education, martal status, houseownership, employement status and age. The second row additionally adds household income. The specifications "Knowledge Vote is in a similar spirt, where knowledge vote is a dummy variable measuning the participant's knowledge on he ballo he has voled upon. Again, he frst row re-estimates the basellne estimates for the voles that had these knowledge questions, and the second row adds the knowledge dummy. The last specification adds a dummy for whether the respondent has kids in the second row. Robust standard errors are reported in parentheses. 
Table A1: Propositions with Predictable Financial Consequences

More Expenditures, Subsidies or Taxes

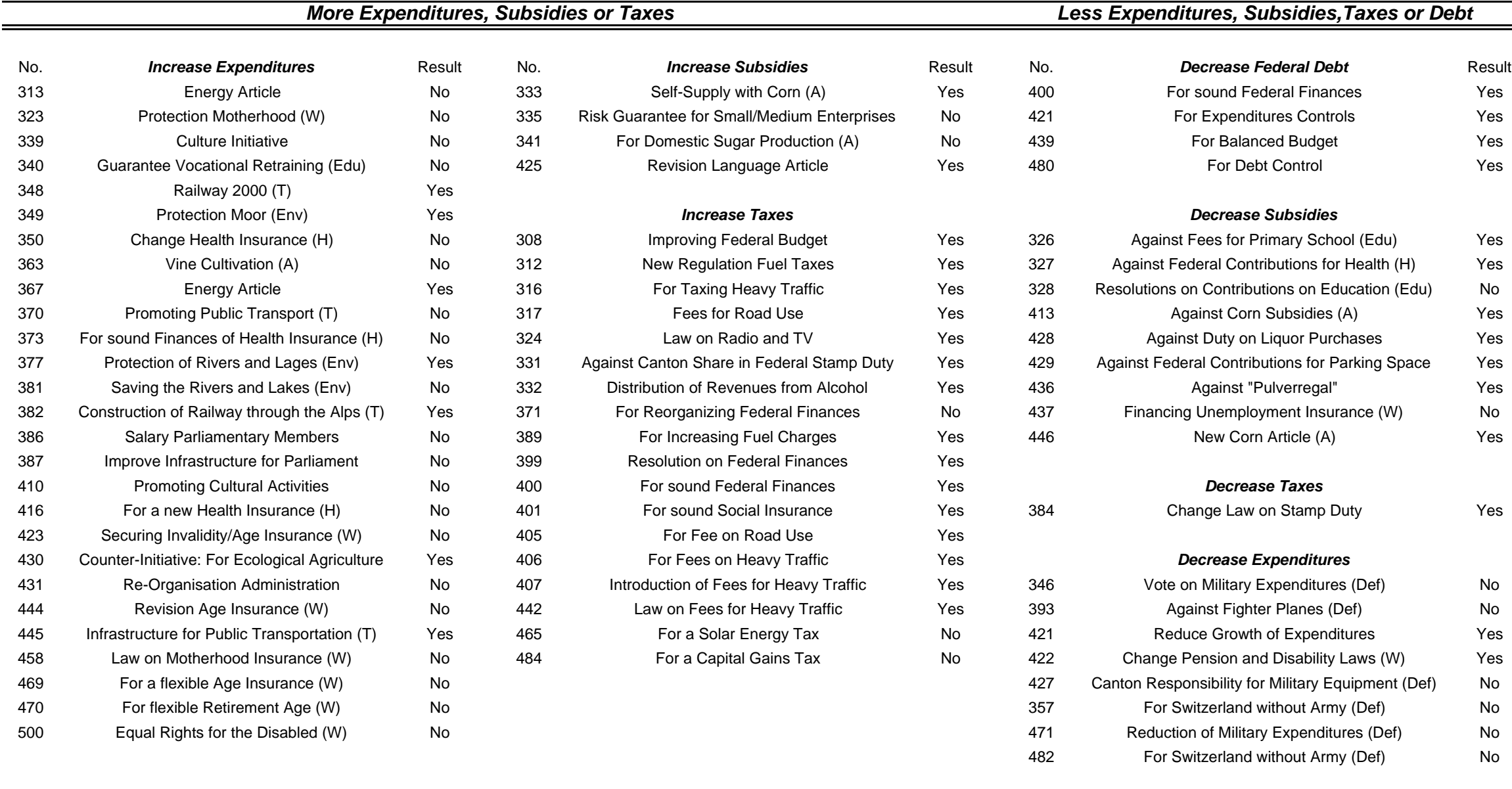

Notes: The table lists all federal propositions between 1981 and 2003, which either led to an increase in federal expenditures, taxes, subsidies, or a decrease in expenditures, taxes, subsidies or public debt. The information is taken from publications of the federal government, which publishes the fiscal consequences for each new law and executive order. Expenditures in individual policy areas are constructed from the respective votes. These are marked after the title using the following abbreviations: (A) for agriculture, (T) for public transport, (Env) for environment, (Def) for Defense, (W) for welfare, ( $H$ ) for health and (Edu) for education.

Source: Federal Archives of Switzerland; available online at http://www.ads.bar.admin.ch/ADS) 
Table A2: Propositions where Men and Women had accepted Different Outcomes

\begin{tabular}{|c|c|c|c|c|}
\hline Title of Proposition & Year of Vote & Women Yes & Men Yes & Outcome \\
\hline Ecological and Modern Agriculture & 1995 & 44.4 & 50.2 & No \\
\hline Easier Access to Swiss Real Estate for Non-Residents & 1995 & 43.3 & 55.4 & No \\
\hline Abolish Subsidies for Parking Spaces at Train Stations & 1996 & 51.8 & 41.2 & Yes \\
\hline For a Sustainable Unemployment Insurance & 1997 & 38.9 & 52.1 & No \\
\hline New Regulation Fuel Tariffs & 1983 & 48.1 & 57.0 & Yes \\
\hline Introduction of Civil Service & 1984 & 51.8 & 44.6 & No \\
\hline Reduce Property Sales, especially to Non-Residents & 1984 & 50.9 & 48.4 & No \\
\hline Stop Construction of Nuclear Power Plants & 1984 & 53.9 & 47.7 & No \\
\hline Stop Use of Nuclear Energy & 1990 & 58.0 & 43.3 & No \\
\hline Reducing Animal Testing & 1992 & 55.4 & 41.7 & No \\
\hline For an Ecological Military & 1993 & 51.3 & 42.9 & No \\
\hline Against Fighter Planes & 1993 & 52.1 & 43.4 & No \\
\hline Flexible Retirement Age 62 for Men and Women & 2000 & 50.4 & 43.6 & No \\
\hline For Equal Rights of the Disabled & 2003 & 55.1 & 40.5 & No \\
\hline Stop Construction of Nuclear Power Plants & 2003 & 50.4 & 44.0 & No \\
\hline
\end{tabular}

Notes: The third and fourth columns show the percentage of women and men voting in favor of the proposition respectively. The last column shows the official outcome of the federal proposition. The first four rows show the votes where women changed the result. The other rows report the votes, in which men were decisive.

Source: VOX Surveys, 1981-2003. 